\title{
Poverty, marginalisation and the quest for collective wellbeing in the context of homelessness in the City of Tshwane ${ }^{1}$
}

\section{Credo Mangayi ${ }^{2}$}

\begin{abstract}
The aim of this article is to contribute towards a solution for addressing poverty and marginalisation associated with homelessness in the City of Tshwane. Twenty-six (i.e. 11 men and 15 women) homeless people were engaged through Contextual Bible Study to gain insights from the margins about appropriate actions to be considered for a transformative missiology in this context. Based on their encounterological reflection of Luke 16: $19-31$ and for the vision of total freedom and collective wellbeing still to be realised in this city, this local homeless community suggested three key actions i.e. (1) partnership and collaboration to end poverty and marginalisation, (2) empowerment for social change and justice and (3) fostering mutual respect to be implemented 'here and now.'
\end{abstract}

Keywords: poverty, exclusion, marginalisation, homelessness, collective wellbeing, justice and City of Tshwane

\section{Introduction}

"Here and now... we have to find solutions (about homelessness) and not wait for tomorrow, because what will happen if there is no next time?" suggested one of the participants of this research during a Bible study discussion. The urgency underlined in this suggestion indicates desperation and a dire need for change in their current circumstances. Tomorrow, solutions might be too late:

The lot of street people, street children, collectively "the homeless", is a terrible and hard-to-face indictment of the caring, compassionate and human rights-oriented ethos of the new dispensation in South Africa. Those living in doorways, under bridges, on pavements and in abandoned buildings have a hard life. The indignity of it all cries out for attention: hungry, dirty, addicted, cold and wet in winter, sometimes involved in prostitution and petty crime, jobless and

1 This article was published as a chapter in the peer-reviewed book Pavement Encounters for Justice: Doing Transformative Missiology with homeless people in the City of Tshwane (Mashau \& Kritzinger 2014), that was a result of the Meal of Peace Project of the Dept. of Christian Spirituality, Church History and Missiology at Unisa. The editors and the authors (as copyright owners), have given permission that this version may be published in Missionalia, as an accredited South African journal

2 Rev C Mangayi is a lecturer in the Department Christian Spirituality, Church History, and Missiology at the University of South Africa. He can be contacted at mangal@unisa.ac.za 
unskilled - but surviving by picking through the rubbish discarded by the wealthy in the form of left-over food and recyclable items like cardboard, glass and tins. Unloved and unwanted, shunned and ignored, bullied in police raids whenever a "clean-up" is ordered - homelessness is not a soft option as a lifestyle choice (Hoffman 2014:1).

One could wish that what Hoffman has described is not true about the plight of the homeless people in South African cities. Sadly, it is true. The homeless people in our cities are not only the poorest of the poor, but also the most affected by exclusion and marginalisation. With reference to the City of Tshwane (CoT), the Pretoria News (2 August 2012) writes "Homelessness is a problem experienced throughout SA, but is on the increase in Tshwane due to migration and the incorporation of Kungwini (Bronkhorstspruit) and Nokeng tsa Taemane (Cullinan) into the city." This phenomenon should not be explained as easily as that and should not be seen in isolation from other broader realities such as urbanisation and the high rate of unemployment faced in this country. In the same vein, Du Preez (2014:1) writes:

The last two decades of urbanisation in South Africa have brought with them more bad than good and have contributed to the crisis the country is in now. The first is the pace of people moving to urban areas: about one million a year (the last reliable figure I could find was 5.5 million between 1996 and 2001). The second is the alarming inability of local and provincial governments to cope with the influx.

Many of these people moving to cities end up in poverty and some become homeless. Although the post-apartheid City of Tshwane has experienced economic growth ${ }^{3}$, poverty and marginalisation remain a common reality for pockets of communities such as the homeless in the city. De Beer (2008:3) rightly says: "The liberation of 1994 has bypassed many mute victims who make the streets their home." This simply means that the dream for collective wellbeing in the city has been elusive and unattainable. Every day, homelessness, coupled with poverty and marginalisation, constantly remind us as we walk through the streets of the "Jacaranda" city that there are people who are still trapped in an endless cycle of poverty. The presence of the homeless community cannot be ignored, neither wished away. It is an issue which must be addressed so that collective wellbeing could one day be realised in the city.

3 The 2012 South Africa Survey shows that "the City of Tshwane has experienced on average 3.6\% economic growth from 1996 to 2011 . The formal employment growth has been on average $3.5 \%$ from 2002 to 2011 . Yet the proportion of people living in poverty has gone up from 18.5\% in 1996 to 19.3\% in 2011" (Dimant 2012: 122 - 123) 
This article attempts to contribute towards a solution to address poverty and marginalisation associated with homelessness. Hence, the question central to this research is: "What could the insights be from a local homeless community that could inspire actions to ensure that all people come to enjoy total freedom and wellbeing?"

In the process of answering this question, this article will firstly provide a theoretical background by placing the topic within the broader contextual issues associated with poverty and marginalisation. Secondly, a brief methodological approach will be described. Thirdly, theological reflection will ensue in an attempt to reflect on Luke 16:19-31 in relation to poverty, marginalisation and a/the quest for collective wellbeing. Fourthly, through an "encounterological' reflection, the voice of the homeless community will come to bear on Luke 16:19-31 in a way which will enable them to state their views and apply their understanding to it in relation to their context. Fifthly, a synthesis of what the homeless community said about the text will be done in comparison with the views of the trained reader (which transpired during theological reflection). This is done in a way which allows the emerging voice of the homeless community to be heard and considered, in order for remedial action to be envisaged. Finally, a conclusion and recommendation will be tabled.

\section{Poverty and marginalisation}

No human being wishes to live in poverty, no matter what the circumstances are. In essence, we concur with what Adam Smith articulated in the nineteenth century in his book entitled An inquiry into the nature and the causes of wealth of nations, when he said that "No society can surely be flourishing and happy, of which the far greater part of the members are poor and miserable" (Smith 1863). With reference to the City of Tshwane, where the poverty rate was 38\% in 2001 (Human Sciences Research Council 2004:1) and after nearly two decades is as high as $27.9 \%$ (Cronjé et al. 2014:60), there are too many people who live in poverty and are miserable. Further, Cronjé et al. (2014:60) highlighted that there is $24.2 \%$ general unemployment, $32.6 \%$ youth unemployment and $14.9 \%$ of the population with no income in the City of Tshwane. Admittedly, homeless street people are the category most affected by poverty and unemployment. And as long as practical and sustainable solutions to address poverty are almost ineffective, these numbers will continue to increase in cities such as Tshwane as a result of the ongoing exodus to cities. Du Preez (2014:1) states: "The proportion 
of South Africans living in urban areas increased from 52\% in 1990 to an estimated $65 \%$ to $67 \%$ in 2014 ."

Many of these people resort, at times through land invasion, to settle in informal urban areas (known as squatter camps) around townships such as Soshanguve, Laudium and the like, where the prospects for employment are bleak. Nationwide, "there are more than 3000 squatter camps in and around our cities and big towns today" (Du Preez 2014:1). Squatter camp dwellers live in poorly-built shacks. Du Toit (2010) writes that the South African Homeless People's Federation regards informal settlement dwellers as "homeless'. However, in comparison to street homelessness, the difference is they have some sort of a shelter to go to every day. This research focuses only on Street homeless people in the City of Tshwane.

Referring back to street homeless described earlier by Hoffman, it is clear that homelessness is the worst form of poverty. This form of poverty dehumanises, marginalises, excludes and makes people suffer in a holistic way. Homelessness displays poverty in a multi-dimensional and multi-faceted manner. Poverty on its own is very complex to address, and I suppose it is even more complex when it is coupled with homelessness. Nevertheless, scholars have generally come to understand that "no single sector can alleviate poverty on its own" (Corbett \& Fikkert 2009:13). As a country we have come to realise that poverty is one of our biggest crises, since it requires all structures and organisations to continue to work tirelessly to eradicate it through transformational development project and programmes.

As Bongani Mayimele (2011) of the South African Non-Government Organisation Network said, "The need for, and pursuit of, development and prosperity is synonymous with human aspirations for a better life." Attaining a better life is certainly one of the reasons at the centre of most development efforts aimed at alleviating poverty, in addition to safeguarding basic human rights and improving the quality of people's lives towards a life characterised by freedom and free from want and isolation (see Alkire 2010:12, Human Development Report 1990:iii).

We have alluded to the intertwined nature of poverty with marginalisation, exclusion and the like. But what is poverty? Why does it lead to marginalisation? There are no easy answers to these questions because poverty is a complex phenomenon, as previously stated. This complexity makes generalisation problematic because each context is different. Institutions such as the World Bank have struggled to define poverty because of its complexity. The Bank realised that true experts on 
poverty are the poor themselves (Corbett \& Fikkert 2009:52). Hence, at the turn of the new millennium, the World Bank collected the voices of more than 60,000 poor women and men from 60 countries, in an unprecedented effort to understand poverty from the perspective of the poor themselves (Narayan et al. 2000). This research shed much-needed light in terms of our approach to dealing with poverty in context. It asserted the fact that a fit-all solution approach is not ideal.

With reference to their own praxis and in relation to the Voices of the Poor Report, Corbett and Fikkert (2009:53) observed that middle to upper class members of North American communities describe poverty differently from the way that the poor in low-income countries do:

While poor people mention having a lack of material things, they tend to describe their condition in far more psychological and social terms than the North American audiences. Poor people typically talk in terms of shame, inferiority, powerlessness, humiliation, fear, hopelessness, depression, social isolation and voicelessness.

From the abovementioned, it is clear that the way we define poverty plays a major role in determining the solutions we use to design interventions for poverty alleviation. Hence, a holistic contextual understanding of poverty is therefore essential in order to deal with the human face suffering from this deprivation trap associated with poverty. Silber and Yalonetzky (2014:26) highlight that the deprivation associated with poverty could be distinguished between "individual and social level" and that it is distributed unequally in various contexts. The fact is that poverty never occurs in isolation; it is rather an interactive system of material poverty, physical weakness, isolation, vulnerability and powerlessness (Chambers \& Conway 1991).

In the same vein - and with reference to the tasks of the church towards poverty alleviation - the contributions of Bryant Myers (1999), Tim Chester (2004a) and the Micah Network Declaration on Integral Mission (2001), amongst others, have started to shape the praxis of many development organisations. Essential to these contributions is integration of proclamation and demonstration of the gospel in contexts of poverty. Also, these contributions recognise that the Bible does give valuable insights into the "nature of human beings, of history, of culture, and of God to point us in the right direction" (Corbett \& Fikkert 2009: 56, see also Steward 1994) when attempting to address the issues of poverty.

In order to diagnose the disease of poverty correctly, Myers (1999:27) says, "We must consider the fundamental nature of reality, starting with the Creator of that reality" (see also Miller 2000). He further explains that 
before the Fall, God established four foundational relationships for each person: a relationship with God, with self, with others, and with the rest of creation. For Myers, the description of the fundamental nature of poverty is linked to a dysfunctional web of foundational relationships. Specifically, he says: "Poverty is the result of relationships that do not work, that are not just, that are not for life, that are not harmonious or enjoyable. Poverty is the absence of shalom in all its meanings" (Myers 1999:86). With reference to homeless people in our context, insights from Myers are helpful in guiding us to identify and analyse these dysfunctional relationships that continue to breed injustice and compromise the attainment of a better life and shalom.

The absence of shalom has manifested itself in a massive exclusion of the poor, especially in this globalisation era. In the face of these unjust imbalances in the world economic order, there is the need to create coalitions of compassion such as the Micah Network, in order to do integral mission for the restoration of justice and peace in the world:

Integral mission or holistic transformation is the proclamation and demonstration of the gospel. It is not simply that evangelism and social involvement are to be done alongside each other. Rather, in integral mission our proclamation has social consequences, as we call people to love and repentance in all areas of life. And our social involvement has evangelistic consequences as we bear witness to the transforming grace of Jesus Christ (Haw 2001:1).

From the foregoing, it is clear that thinkers and practitioners are increasingly realising that integrated and holistic interventions stand a chance of alleviating or even eradicating poverty. Corbett and Fikkert $(2009: 13,60)$ are right in suggesting that "appropriate interventions for poor people include sectors as diverse as economic development, health, education, agriculture and spiritual formation" (see also Haw 2001, Perkins 1995). This is so because "the multi-dimensional nature of poverty enjoys broad consensus" among scholars and practitioners (Silber \& Yalonetzky 2014:9). In contexts of extreme poverty, such as street homelessness in South Africa, the multi-dimensional nature of poverty naturally engenders a multi-dimensional entrapment. Therefore, only a holistic and multidimensional intervention will stand a chance.

Kofi Annan, Chairperson of the Africa Progress Panel, points to this fact in the report when he says that "disparities in basic life-chances - for health, education and participation in society - are preventing millions of Africans from realising their potential, holding back social and economic progress in the process" (Annan, cited by Africa Progress Report 2012). It is therefore important for us in missiology to understand that behind these millions of Africans there are, in the words of Linthicum (1991b:7) 
"individual stories, stories of poverty, of sickness and despair, stories of people who are unable to influence the course of their own lives and are powerless to change the course of their neighbourhoods or cities." Yet, on the ground, the reality of poverty seems at times invisible because we do not see the faces of the poor or hear their stories. Conn and Ortiz (2001:325) add: "They are invisible to us, or they are pictured as living so far away that they have nothing to do with us." As a result, they are further excluded and marginalised.

That is why we opted in this project to get closer to the homeless community in Pretoria for two reasons. Firstly, it gives us an opportunity to get to see their faces and hear their stories. Secondly, through this project we get to reduce the social distance which has prevailed between us and the poor in our city. Also, it gives us the opportunity to address the instances of exclusion and marginalisation this community suffers from, in the hope that we can contribute towards restoring justice and peace amidst the brokenness that exists.

\section{Poverty and homelessness}

Although many communities are poor in South Africa, it is not the same for the people who are poor and homeless in the city. People in many rural areas of South Africa could be classified as poor due to income level or lack of it, but at least these people have a home. This is not so for the poor and homeless people in the streets of our cities. If, as stated earlier, poverty dehumanises, excludes and marginalises, homelessness is the worst manifestation of poverty in that it pushes the poor people to become not only "wanderers" but "beggars" as well. As a result, they are misunderstood and misperceived. Ratepayers prefer not to have to see and deal with the homeless; they usually force the authorities to remove them from their neighbourhoods (Hoffman 2014: 1). Their plight is simply ignored and misunderstood.

In the same vein, Mae Cannon (2009:174-175) writes from a United States of America perspective: "In the late twentieth century, people used to believe that the homeless were mentally ill or suffered from psychological problems. Other perceptions were that homeless people were not willing to work or were unable to hold down jobs." Hence, to avoid being caught in these misperceptions, homelessness has to be defined in our context. Olufemi (cited by Naidoo 2010:130) defines the homeless as including, inter alia, "those living in squatter / shack housing, as well as those living on the streets or pavements (chronic or transient homeless)." The research participants for our project fall into three categories: those living on the 
streets, those living in shack housing in backyards at Salvokop ${ }^{4}$ and those living temporarily in a shelter. It was important to observe that none of these participants claim to have a home when asked where they live. It was as if they felt excluded, marginalised and not welcome in the city. Admittedly, it is complex to "distinguish the street homeless, in policy interventions, from people who are inadequately housed" (Naidoo 2010:131). In this contribution, I agree with Tipple and Speak (cited by Naidoo 2010:131) "that people living on the streets, under bridges, and in structures not designed for residence are homeless."

According to Olufemi, the following social and economic factors put many people at risk of homelessness in South Africa: "poverty, nonaffordability of rent, unemployment, family disintegration, physical abuse, lack of skills, partial education or none, and violence (Olufemi 2002:460). In an interview with the Cape Argus newspaper, Donald Grant (Minister of Education in the Western Cape Province) said: "The education problems within South Africa contribute to the high rates of unemployment and homelessness" (Manwaring 2012). Grant's statement is based on the fact that there are people with qualifications not suited for the job market; hence they end up being unemployable and at risk of homelessness.

The forced removal of communities under Apartheid has also played a negative role with regard to homelessness in South Africa. For instance, Manwaring (2012) elaborates: "The destruction of District Six displaced thousands of families - black, white and coloured - all of whom became homeless. These people were offered meagre compensation for their homes and were forced to start new lives in different areas farther from the city." Du Toit (2010:2) affirms this by pointing to a study conducted in the inner city of Pretoria:

A brief study by Aliber et al. (2004) of the homeless who slept in front of the HSRC building revealed that, apart from some detached homeless persons, most of them had homes and social ties in townships and informal settlements. These people were searching for work in central Pretoria but could not afford to commute daily from townships or informal settlements outside Pretoria. As a result, they felt they had little choice but to sleep on the streets in the inner city.

4 Inkululeko Community Centre, one of the programmes of Tshwane Leadership Foundation, is situated in Salvakop. According to Tshwane Leadership Foundation, Salvokop is a housing area on the south-west corner of the inner city of Pretoria and is characterised by: •A multi-racial and multi-ethnic community; •A high rate of wellskilled but unemployed youth and adults; •An infrastructure and houses with the potential to be a very attractive neighbourhood; $\bullet$ A community which has organised itself into SMMEs or closed corporation businesses; $\bullet$ The Freedom Park development, which promises to become a major tourist destination 
To add to the discourse above, other factors associated with homelessness in Tshwane include asylum seekers, who fled war and violence in their countries of origin, and economic migration. Some of these homeless immigrants choose to sleep on the streets or seek shelter in the city rather than go to live in a township, for fear of xenophobia. Nonetheless, homeless folks, regardless of race, ethnicity, religion and culture, are entitled to be cared for and protected if we are to build an inclusive and caring city where collective wellbeing is a reality. The City of Tshwane's (2013:29-30) policy on homelessness distinguishes between two categories: transitional and chronic homelessness.

Under transitional homelessness, they include: 1) people who do not have a home and who may be waiting for housing from the Human Settlements Office; 2) people who are temporarily employed in occupations such as parking assistants, informal retailers, collectors of papers and cans who do not have the resources to travel to and from townships or informal settlements every day; 3) job-seekers, many from out of town; and 4) people displaced from homes due to family conflict.

Under chronic homelessness, they include: 1) people who are mentally ill or suffer from diseases; and 2) people who have fallen out of a social network, often due to personal or domestic circumstances such as domestic violence, conflict, or people who have lost their families, spouses, or life partners who supported them. Discourses and arguments presented in the foregoing have attempted to describe poverty and marginalisation in relation to homelessness. The next section will attempt to highlight what could be done in order to realise collective wellbeing.

\section{Wellbeing as the eradication of poverty and marginalisation}

\section{Hoffman (2014:1) rightly says:}

It is difficult to square a policy that has this inevitable outcome with the values of the Constitution. Our Bill of Rights requires the state to "respect, protect, promote and fulfil" the rights in it. These include life, dignity, and freedom from violence, preservation of bodily and psychological integrity as well as the progressive realisation of access to housing and the Section 27 rights to health care, food, water and social security. Placed in the constitutional context of governance that is transparent, accountable and responsive to the needs of ordinary people, it is plain to see that the authorities have no plan and no sustainable policy for addressing the lot of the homeless. 
In his article: “Taking back our streets: Reading Steve Biko's Black Consciousness and the quest for true humanity on the streets of Tshwane", De Beer (2008:15) cites Alexander: "Movements for dignity and liberation should be about dismantling whatever is anti-human, wherever it occurs." Poverty and marginalisation of the population, including the homeless, is anti-human. Furthermore, drawing from Biko's notion of consciousness, he writes:

Firstly (...) we should engage in awakening the people - people in the streets, people in their pews and well-off people - from their own psychological oppression or numbness, recognising their inferiority complex or their ignorance. Secondly, we must engage in an awakening from our physical oppression, living in a society shaped by capital, markets, race, class, gender and/or global economic patterns (...), an oppression of barricaded communities and sprawling informal settlements coexisting side by side, with their mutual intolerance and their inability to break down the fences (De Beer 2008:15).

De Beer is suggesting something beyond welfare responses such as shelter, food pantry, addressing substance abuse issues, crime and the like. He suggests an individual and collective introspection of our motives and actions in relation to homelessness. Thus, in our quest for collective wellbeing, the power and systemic injustices that push these people to the margins must be analysed and exposed so that better alternatives could emerge. The "awakening of the people" that De Beer suggests is an important step in this process. Without this, the government and non-governmental organisations, including the church, will continue to relieve symptoms and leave the root causes unchallenged. Worse, this relief is often done without a genuine input from homeless people themselves. As a result, some of them have come to accept relief as the only form of poverty eradication befitting their situation, instead of self-empowerment, transformation and liberation. However, research has shown that homeless people do think beyond welfare and relief as far as their situation is concerned. When they were asked about the most important thing the municipality could have done for them, the findings show the following:

More than half of the homeless persons here $(53.7 \%)$ chose 'provide employment'. The second largest percentage (34\%) opted for housing. Very few opted for support $(7.3 \%)$. Those who chose housing were also asked what kind of housing would be most useful, given their current circumstances and where such housing should be located (...). The majority $(62.8 \%)$ opted for affordable self-owned housing, whereas only $18.9 \%$ opted for affordable rental housing and $18.2 \%$ for 
a place in a shelter for the homeless. Interestingly, a larger proportion of those who opted for a place in a shelter thought that shelters would be best located near town and other places of economic opportunities, whereas a larger proportion of those who opted for affordable rental housing or self-owned housing thought that such housing would be best located in a local township or suburb respectively (Du Toit 2010:15).

These findings give an indication of what the homeless who participated in that survey see as appropriate mechanisms to address their circumstances. It is significant that more than half see provision of employment as priority number one, housing as priority number two and support as priority number three. I deduce from these findings that there seems to be a correlation between unemployment and homelessness, which is why more than half of the group chose "provide employment" as their top priority. This group could be made up of "internally displaced people" who have come to seek employment in the city and can't afford decent accommodation. They fit into the "transitional homeless" category described in the Homeless Policy of the city. With regard to the group that opted for housing as top priority, it is obvious from this survey that most of these homeless people dream of affordable self-owned houses; they want to settle in their homes in the local townships. This, in a way, provides a permanent inclusion in a community that they visualised happening. Renting and living in shelters are merely temporary solutions to the homelessness they are currently experiencing.

In summary, wellbeing for homeless persons has to do with employment and housing. Through employment and housing, they will be liberated and empowered to the point where they become self-reliant, get their dignity back and are socio-economically included in the city.

\section{Research Methodology: Contextual Bible Study}

This study is part of a community-engaged action research project aimed at "doing justice in the context of homelessness" in the inner City of Tshwane. With specific reference to this Bible study, the twenty-six homeless people (11 men and 15 women) who agreed to participate in this research were divided into four small groups. They were involved in a Scripture-based focus group discussion known as Contextual Bible Study (CBS), developed by Gerald West and the Ujaama staff. The discussion took place on 27 June 2013 from 08:45 until 13:30. It was 
facilitated by the researcher, assisted by two colleagues. The process started with a short praise and worship item, then a short prayer led by the researcher. It was followed by a self-introduction of both the group and facilitators. CBS is concerned with Biblical interpretation that is proactive, where recognition of the ordinary reader is given centre stage in the African context, as subjects of Biblical interpretation. It befits liberation and inculturation methodologies.

In relation to this study, firstly the text (Luke 16:19-31) was read in order to get a general impression about what the text was about in relation to poverty, marginalisation and the quest for collective wellbeing in the context of homelessness. Through this interaction the group tried to understand the issues associated with this topic. All the inputs were captured on newsprint, but not much discussion was allowed at this stage.

Secondly, Luke 16:19-31 was discussed in small groups, with the interaction being guided by the following set of questions:

- According to Luke 16:19, what are the things that portray riches and wealth?

- How do verses 20-21 describe the condition of someone in poverty?

- Why did Jesus speak of the reality of death (v.22), hell (v.23), comfort and judgement (v.24-26) in this text?

- What can we learn from this text (v.27-31) about life and the purpose of material possessions in one's life?

- Who in your context needs food and comfort? Why?

Inputs generated by each small group were tabled and discussed. Participants were allowed to comment on inputs from other small groups to add or seek clarification.

Thirdly, the same text was read in such a way that the issue of poverty, marginalisation and the quest for collective wellbeing was interrogated in relation to our contemporary context. It was expected of the participants to use the text in a "prayerful and intelligent way in order to hear the voice of God for our particular context" (Kritzinger 1998:17) in relation to poverty, marginalisation and the quest for collective wellbeing in the City of Tshwane. The interaction was guided by these questions:

- Who in your context needs total freedom from various forms of slavery? Why?

- What temptations and evils will prevent us from realising total freedom and peace for all? 
Inputs from various small groups were once again tabled and comments were invited from participants.

Finally, the text was read in such a way that clues for transformation were singled out as a plan of action to address the issue of poverty, marginalisation and the quest for collective wellbeing. Simply put, this text was read with the expectation that it will give directions on how to change the situation in which homeless people find themselves. The question for this step was:

- What will you do to ensure that all people come to enjoy total freedom and peace?

- Write down your plan of action.

Inputs from the group were listed on the newsprint. Then a vote of thanks was expressed to the group for their active participation and a prayer was said to close the process. Lunch was served at the end of the process at 13:30.

Now that the methodology has been described, we will look into this text from the trained reader's perspective.

\section{Theological reflection of Luke 16:19-31 on poverty, marginalisation and the quest for collective wellbeing}

This section discusses Luke 16:19-31 from the perspective of the trained readers of the Bible. According to Northcott (1998), this parable of Dives $^{5}$ and Lazarus is difficult to interpret by trained readers of the Bible who seek to harmonise Christian teaching with the dedicated pursuit of wealth, especially in modern capitalist and market-dominated societies. Presumably, as Gail O'Day (1992:118) says, this text "invites us into God's world of compassion from the side of human pain and human resistance." Lazarus represents human pain and, in stark contrast, the rich man portrays human resistance and selfishness. The contrast between wealth and poverty in this parable is as vivid as day and night.

In addition, critical issues related to Christian ethics come to the fore in this text, which hinge on the one hand on the Decalogue itself (embracing the dual code of religious duties (Exodus 20:3-12) and social duties (Exodus 20:13-17), followed by the prophets who portrayed God as passionately defensive of the poor and oppressed, passionately opposed to

5 The Latin word dives (rich) is used in the Vulgate for the rich man. The traditional title given to this parable (Dives and Lazarus) has led some people to think (wrongly) that Dives was his name. 
cruelty, deceit, luxury and selfishness (see Amos). On the other hand, there is the pre-eminence of love - "Love the Lord your God ....and love your neighbour as you love yourself" - as the guide for ethics.

In essence, the pain of Lazarus was begging for a remedy, a "right deed" from the rich man and the community: "We may say generally that if the parable of the unjust steward teaches how riches are to be used, this parable sets forth the terrible consequences of a failure to use them" (The Fourfold Gospel 2008:511). I contend that the consequences suffered by the nameless rich man, whose garments and continual banqueting indicate a life of extreme luxury, were proportionate to the failure to use his riches as a just steward. Ethical stewardship of riches in a way which should have benefited Lazarus was expected of the rich man. Especially since "there is nothing to indicate that he had been a habitual beggar" (The Fourfold Gospel 511-512).

It is therefore probable that Lazarus was a victim of an unjust economic system which led to his losses and caused him to become a beggar, to the point where he started desiring crumbs instead of a banquet, in addition to being marginalised and excluded. Mealand (cited by Northcott 1998:104) alludes to this fact when he says, "The parable is set in a society where a small minority of rich merchants flourished through collaboration with the Roman occupiers of Palestine, while the majority languished, like Lazarus did, in debt, economic insecurity and ill-health." As I stated earlier, the same is the case today with some of the homeless people in the City of Tshwane who have found themselves on the streets because of unemployment which has resulted, in my view, from a coalition between economic and political powers and systems. It is as if the world has not changed. This appears to be so because of the prevailing modern capitalist economic system which tends to maximise profit and economic growth (wealth) at the expense of collective wellbeing.

However, generating wealth in itself is not an evil thing. The Biblical perspective sees wealth within a frame of reference whereby God is the owner of all things (see Genesis 1-2, I Chronicles 29:11, Psalms $24: 1 ; 50: 12 ; 89: 11$, Isaiah 66:2) and humans as stewards of wealth for God's purposes (see Deuteronomy 8:11-20; Leviticus 19:918, Job 31:16-33, Isaiah 58:6-10). Therefore, wealth is part of worship (see Numbers 18:21-29, Deuteronomy 12:6-7; 14:28-29; 26:12-15) and wealth is also seen as a gift from God for Covenant fidelity (see Deuteronomy 27-28, Proverbs $3: 10 ; 8: 20-21 ; 10: 22 ; 15: 6)$. Hence, there are warnings against wealth at the expense of others (see Proverbs 21:6, Jeremiah 5:26-29, Hosea 12:6-8, Micah 6:9-12). It is clear from the 
Biblical perspective that wealth (economic growth) is not evil in itself, unless it is achieved in a way that exploits and marginalises sectors of the population, as we have experienced in South Africa. The homeless are such people in the City of Tshwane. Plainly put, the homeless portray a "Lazarus syndrome" while those who are benefiting from the economy embody a "Dives opulence." This polarisation must be addressed if collective wellbeing is to be attained.

In order to achieve collective wellbeing, I contend that repentance has to affect wealth (Luke 19:2-10) and economic exploitation must be condemned (Mark 12:38-40). For me, I concur with 2 Corinthians that accumulation of wealth must be balanced with true worship and responsible stewardship (cf. 2 Corinthians 8-9). With reference to Tshwane, this implies that a focus on economic growth should be commensurate with social responsibility towards the poor and marginalised. In relation to the current situation of homeless people in the city, I argue that a modus operandi of social responsibility geared towards collective wellbeing has to: 1) address the issues associated with living on welfare; 2) foster love, justice and sharing; 3 ) go beyond equality before the law; and 4) develop relationships of justice.

Making the homeless people in our context live forever on welfare will not address structural issues which keep them in a socio-economic bondage that breeds marginalisation, voicelessness and powerlessness. On the contrary, fostering love, justice and sharing has to focus on personal relations and good patterns of distribution of resources. Forrester and Skene (1998:113) rightly state: "Healed - healthy relationships must express themselves in the way we share things, in patterns of distribution" (see also Haw 2001:3). Hence, that homeless person on the streets is a fellow human being (equal to any other human being before the law) who is entitled to be loved and to benefit from the mutual sharing of resources - material, spiritual and social - in a community, so that peace and justice are realised.

Sharing has to go beyond equality before the law in such a way that "income which is the most important of these resources" (Atherton 1998:117) is accessible to the people on the margins, such as the homeless. Atherton (1998:118) continues: "A basic income guaranteed for everyone provides an essential base from which human fulfilment can be pursued. It does not guarantee fulfilment, but at least it makes it possible." In addition, it is crucial in dealing with poverty and marginalisation and for the sustainability of love, sharing and income that relationships of justice be established across systems and powers in society. Russell (1998:121-122) is right when he states: "It requires 
preventive change, not just amelioration," because current solutions and interventions patch matters up rather than attack the root causes. Reasons for these causes, continues Russell (1998:122), "are based on the self-interest of the non-poor majority." Usually, non-poor communities tend to preserve the status quo and maintain social fragmentation that leads to a divided society, as we are currently experiencing the world over.

In an attempt to sketch a pastoral praxis which could address the issues highlighted in this text and discussion above, Mangayi (2014:16) writes: "It is fundamentally a problem of exclusion i.e. economic exclusion. Lazarus is not welcome at the table of the rich man." In relation to this text, Maluleke (2014) suggests that Christian mission should focus on "rescuing Lazarus before he dies." According to Maluleke (2104), this includes: (1) replacing hope for crumbs with hope for bread; (2) making Lazarus visible and seeing Lazarus; (3) recognising the emergence and emergency of Lazaruses; (4) making the link between the poverty of Lazarus and the wealth of the men (and women) of "linen;" (5) appreciating the initiative and creativity of Lazarus; and (6) saving Lazarus before, not after, he dies. In order to be consistent with love, justice and sharing and realised collective wellbeing, Mangayi (2014:19) suggests that "Lazarus has the right to sit and feast at the table." He must not be excluded.

\section{Encounterological reflection on Luke 16:19- 31 in relation to poverty, marginalisation and the quest for collective wellbeing}

The text of Luke 16:19-31 was used for reflection. For the participants of the contextual Bible study, this text speaks about a number of things such as repentance while one is alive, sharing, judging each other, and about the rich man who did not care about the kingdom of God. It is also about doing good while you can and not isolating yourself when you are rich. The participants stated that true riches are from the heart. Hence, humanity has to be mindful that there is life after the grave and death is a common denominator. Other opinions expressed by participants included: it is about sharing the gospel and about God who offers second chances. Participants also highlighted the fact that things change, pointing to the temporary nature of human life. With regard to the main idea of the passage, the group stated that it seems as if God is on the side of the poor. 
Drawing specifically on Luke 16:19, participants identified the following things that symbolise the riches and wealth of the rich man, i.e. most expensive clothes (e.g. royal linen and purple garments) and live in luxury in everyday life. Participants added: people who are rich tend to be proud and arrogant, thus exploiting the poor and their concern is mostly about their riches and wealth. They can't sleep at night.

In describing the condition of someone in poverty, the participants, drawing from Luke 16:20-21, said Lazarus was covered with "sores;" he did not have adequate nutrition and hygiene; he longed for food; he was hungry; he relied greatly on his boss for food donations, which he sometimes shared with animals and he didn't have a choice but to accept what was handed to him.

Reflecting on why Jesus spoke in this parable about the reality of death (v.22), hell (v.23), comfort and judgement (v.24-26), participants said it was to stress the point that we are all going to die some day and that death doesn't choose our "wealthiness" or our poverty. One participant stressed that hell is the place for the wicked and that comfort is the place reserved for those who persevere in life. Finally, they stressed the point that the Day of Judgement and reckoning is for everyone.

With regard to lessons learned from this text (v.27-31) about life and the purpose of material possessions in one's life, participants highlighted that we must not hold on to material things and we must share with others who are in need; we must learn about the righteousness of life; life is what is happening now, not what you think will happen tomorrow. They also added that you cannot save your own brother and family from judgement. Hence, learn and listen to the word of God. Further, another lesson the participants mentioned was that we must be solution-minded in a sense of using a "here and now" way of exploring alternatives to find solutions and not wait for tomorrow, because what will happen if there is no next time?

In the process of attempting to apply this text to their immediate context, participants discussed who in their own context needed food and comfort. They said: the rich man after death was in great pain, so he needed comfort from Lazarus. The rich man called Abraham for help - but he was reminded of his deeds on earth. With regard to Lazarus, they said: he needed material and physical comfort on earth but was eternally comforted after death.

Further, when asked who in their context needed total freedom from various forms of slavery and why, participants of Group 1 started by explaining total freedom means to be spiritually poor, which means 
hungry to do the will of God (to be pleasing to him, humble, pure heart, merciful and peace-making). That is why all human beings need total freedom (Groups $1 \& 2$ ), regardless of whether you are poor or materially rich. It also means not to be dependent on others and not to be egotistic (Group 2). Group 3 specifically said that the rich people must be freed of their comfort zone, thinking they are the "cream of this world", and forget that there is total freedom in heaven, provided you are saved for it. Concerning the poor, Group 3 said they needed the freedom of being accepted or recognised in any world's social / life arrangements. On the same question, Group 4 suggested that the rich man needs total freedom, he is blinded by his wealth - he doesn't have time for his spiritual wellbeing and he is arrogant. Furthermore, continued Group 4: the rich people are full of themselves and are selfcentred and dogmatic. Group 5 added that the rich man has no spiritual freedom. He is in great pain in Hades, which shows his suffering. By way of a conclusion on this question, Group 3 submitted that, although God seems to be on the side of the poor, the poor also need to get up and do it for him to receive unlimited wisdom. Group 4 concluded by saying that both the rich man and the poor man need total freedom because much more will be achieved if they work together in a manner which complements each other.

Nonetheless, participants recognised that there are temptations and evils that could prevent us from realising total freedom and wellbeing for all. The following temptations and evils were named: greed (Groups 1, 2 \& 3), lack of love for others (Groups 1, 2 \& 4), accumulating more than enough (Group 2), the love of money (Eccl. 5:10) and longing to be rich (Groups 1 \& 5), deceit and lies (Group 1), pride (Groups 1 \& 5), ego (Group 2), a mind that thinks up wicked plans and stealing (Groups $1 \&$ 4), injustice and unfairness (Group 2), disrespect (Group 4), spiritual adultery and not conforming to the commandments of God (Group 4).

In an attempt to put in place actions to ensure that all people come to enjoy total freedom and wellbeing, participants suggested the following remedies: share the word of God; create decent jobs (the rich man must "come to the party"); serve God as a first priority; teach people to be leaders, not only followers; work together to discover gifts (Eccl. 4:9) of teaching, counselling, preaching, etc.; build relationships with likeminded people and organisations; empower people to put words into actions; mobilise gifts and assets (utilise them for collective wellbeing); treat all people with dignity (irrespective of race, clan, gender, ethnicity, place of origin and social status); and encourage mutual understanding so that we can live freely and happily with each other. 
From this list, the group prioritised key actions, namely: (1) partnerships and collaboration to end poverty and marginalisation; (2) empowerment for social change and justice and (3) fostering mutual respect.

\section{Synthesis: Emerging voice(s) of the ordinary readers of the text}

It is clear from theological reflections that God's compassion is the driving inspiration for addressing poverty and marginalisation and this comes within the observance of what participants referred to as the law of God as a framework. Admittedly, the law of God is implemented through our love for God and for the neighbour. Hence, posing the "right" deed in terms of alleviating poverty (short term) and providing lasting and sustainable solutions to the issues of poverty and marginalisation (long term) befit the requirements of the ethical stewardship expected of humanity by the Creator.

In line with the foregoing, the ordinary readers suggested repentance, sharing and "doing good" to fellow human beings in need. The ordinary readers emphasised sharing and doing good deeds because it is the right thing to do, echoing Proverbs 3:27 (New Living Translation) which says: "Do not withhold good from those who deserve it when it is in your power to help them." The ordinary readers went further in highlighting that the rich man should not live in isolation, since all humanity has a common destiny, namely death.

In essence, the ordinary readers condemned the attitude of the people who are rich, arrogant and proud, tend to exploit the poor and are mostly concerned about their riches and wealth. For them, this attitude has deprived the poor of adequate nutrition, hygiene and food and has made the poor totally dependent on the charity of the rich. Consequently, the poor do not have a choice but to accept what is handed to them. They are further marginalised and excluded from meaningful participation in society.

Both the trained and ordinary readers see the poor as victims of an unjust economic system and that wealth is not evil in itself. Wealth should rather be part of worshipping God - it should be handled as God purposes it, for the benefit of communities. Nonetheless, the ordinary readers add that we should not hold on to material things. The one way not to hold on to material things is by sharing, because humanity belongs together; Lazarus needs the rich man, and vice versa. Yet in order to realise this sharing (which is grounded in ethical stewardship), both the rich and poor must be totally free, suggest the ordinary readers. 
This total freedom means to be spiritually poor - which means hungry to do the will of God (to be pleasing to God, humble, pure at heart, merciful and peace-making). If the rich are not totally free, they are blinded by their wealth, they will be full of themselves and self-centred. The poor also need total freedom so that they can get up to do it for themselves.

Welfare is not enough. The rich and poor must work together in a manner to complement one another, contend the ordinary readers. This point is made explicit when the ordinary readers prioritise the actions urgently needed to address poverty and marginalisation, namely partnership and collaboration to end poverty and marginalisation, empowerment for social change and justice, and fostering mutual respect. There is also urgency expressed by the ordinary readers: we must be solution-minded in the sense of using a "here and now" way of exploring alternatives to find solutions and not wait for tomorrow, because what will happen if there is no next time? The same position was also expressed by Maluleke, as stated earlier, when he said the focus should be on "rescuing Lazarus now, before he dies."

This is achievable if temptations and evils, which are stumbling blocks, are dealt with, acknowledge the ordinary readers. They name (in descending order): greed, lack of love for others, love of money and longing to be rich, wicked minds and stealing, pride, deceit and lies, injustice and unfairness, disrespect, spiritual adultery and not conforming to the commandments of God. For them, these temptations and evils have prevented society from realising total freedom and wellbeing for all.

They contend that these temptations and evils can be dealt with and a process can be facilitated that will lead to collective wellbeing, by sharing the word of God, creating decent jobs, serving God as a first priority, teaching people to be leaders, working together to discover gifts, building relationships, empowering people to put words into actions, mobilising gifts and assets for collective wellbeing, treating all people with dignity and encouraging mutual understanding.

\section{Conclusions and recommendations}

With reference to homelessness, this article has highlighted key insights coming from the margins on what should be considered in a transformative missiology, aimed at finding ways to address poverty and marginalisation in the quest for collective wellbeing in the City of Tshwane. Drawing from insights shared by a local homeless community that could inspire actions to ensure that all people come to enjoy total 
freedom and wellbeing, three key actions are suggested: (1) partnerships and collaboration to end poverty and marginalisation; (2) empowerment for social change and justice; and (3) fostering mutual respect. Finally, this homeless group recommends with urgency that "we must be solution-minded in a sense of using a "here and now' way of exploring alternatives to find solutions and not wait for tomorrow, because what will happen if there is no next time?"

\section{Bibliography}

Africa Progress Report 2012 - Jobs, Justice and Equity: Seizing Opportunities in Times of Global Change, accessed 11 May 2012, from http://www.africafocus.org/econexp.php

Alkire, S. 2010, Human Development: Definitions, Critiques, and Related Concepts, Human Development Research Paper 2010/01, New York: United Nations Development Programme.

Atherton, J., 1998, Going beyond equality, in Northcott, M., (ed.), 1998, Urban Theology, a reader, Cassell, London, pp 117-121.

Cannon, M. E., 2009, Social Justice Handbook: Small steps for a better world, Downers Grove, Illinois: IVP Books.

Chambers, R. \& Conway, G., 1991. Sustainable livelihoods: practical concepts for the $21^{\text {st }}$ century, accessed 13 September 2010, from http://www.livelihoods.org/cgi-bin/dbtcgi.exe

Chester, T. 2004. Barriers to the Embrace of Integral Mission. Micah Challenge Framework Paper 1.

City of Tshwane. 2013. Homeless Policy for the City of Tshwane and Report on public participation. City of Tshwane: Mayoral Committee.

Conn, H. M. \& Ortiz, M., 2001, Urban ministry: The Kingdom, the City \& the People of God, Downers Grove, Illinois: InterVarsity Press.

Corbett, S. \& Fikkert, B., 2009, When helping hurts: How to alleviate poverty without hurting the poor and yourself, Moody Publishers, Chicago.

Cronje, F. et al. 2014. The 80/20 Report: Local Government in 80 indicators after 20 years of Democracy, South African Institute of Race Relations, Johannesburg. Accessed 4 November 2014 from http://irr.org.za/reports-and-publications/occasional-reports/the-8020-report-on-local-government, 
De Beer, S., 2008, “Taking back our streets: Reading Steve Biko's Black Consciousness and the quest for true humanity on the streets of Tshwane." Accessed 23 May 2014, from http:/uir.unisa.ac.za/ bitstream/handle/10500/4331/De\%Beer.pdf.sequence $=1$

Dimant, T., 2012, The economy, in South Africa Survey 2012, pp 97 - 172, South African Institute of Race Relations, Johannesburg.

Du Preez, M. 2014. SA's encroaching crisis: Is the real land ownership crisis in urban areas? Accessed 3 November 2014 from http://www.moneyweb.co.za/moneyweb-political-economy/sasencroaching-crisis.

Du Toit, J., 2010, Local metropolitan government responses to homeless in South Africa, accessed 24 May 2014, from http://repository.up.ac.za/ bitstream/handle/2263/14765/DuToit_Local(2010...)

Forrester, D \& Skene, D., 1998, Love, Justice and sharing: A Christian perspective, in Northcott, M., (ed.), 1998, Urban Theology, a reader. London: Cassell. $113-117$.

Haw, S. 2001. Micah Network Declaration on Integral Mission. Accessed 3 November 2014 from http://www.micahnetwork.org/sites/default/ files/doc/page/mn integral mission declaration en.pdf.

Hoffman, P. 2014. Homelessness in the new South Africa. Accessed 3 November 2014 from http://ifaisa.org/Homelessnessinthenew SouthAfrica.html

Human Sciences Research Council 2004. Fact Sheet: Poverty in South Africa. Pretoria: HSRC. Fact Sheet no 1. July 2004.

Kritzinger, JNJ. 1998. Concrete spirituality: Reading the Bible in the city. Workbook Five. Pretoria: Institute for Urban Ministry.

Linthicum, R.C., 1991b. Empowering the poor: Community Organising Among the City's Rag, Tag and Bobtail. Monrovia, California: MARC.

Maluleke, S. T., 2014, The unholy trinity that sends people to hell fast: poverty, inequality and unemployment. Paper presented at Mission and Money: Mission in the context of Global Inequalities Conference, Helsinki, Finland, 2 - 6 April 2014.

Mangayi, L., 2014, Mission as local economic development in the City of Tshwane: Towards fostering a grassroots, 'glocal' alternative vision, with specific reference to Luke 16:19-31, Unpublished article, University of South Africa. 
Manwaring, C., 2012, South Africa's homeless population, accessed 24 May 2014, from http://blogs.elon.edu/sasa/2012/01/20/south-africashomeless-population

Mayimele, B., 2011, Achieving the objects of developmental local government through the Integrated Development Programme, accessed 24 March 2014, from http://www.ngopulse.org/ node/374/articles.

Miller, D. with Guthrie, S. 2000. Disciplining Nations. The power of truth to transform cultures. Seattle: YWAM Publishing.

Myers, B.L. 1999. Walking with the poor: Principles and practices of transformational development. Orbis, Maryknoll, NY.

Naidoo, V., 2010. Government responses to street homelessness in South Africa, in Development Southern Africa, 27 (1), 129 -141.

Narayan, D. et al. 2000. Voices of the Poor: Crying Out for Change. New York: Oxford University Press for the World Bank. Accessed 3 November 2014 from https://openknowledge.worldbank.org/ handle/10986/13848,

Northcott, M., (ed.), 1998. Urban Theology, A reader, London: Cassell.

O’Day, G. R., 1992. A world transformed from Greed to Gift: Joel 2: 23-30; Luke 16: 19-31, Standing with the poor. Theological reflections on economic reality. Cleveland, Ohio: The Pilgrim Press, 115- 119.

Olufemi, O., 2002, Barriers that disconnect homeless people and make homelessness difficult to interpret, Development Southern Africa, 19(4), $455-66$.

Perkins, J. M (ed.). 1995. Restoring At-Risk Communities: Doing it Together and Doing it Right. Grand Rapids: Baker Books.

Pretoria News. 2012. Bid to get homeless off city streets. (http://www.iol.co.za/pretoria-news/bid-to-get-homeless-off-citystreets-1.1355113\#.VFeGwU0U_1I [accessed 3 November 2014].

Russell, H., 1998. Relationships of justice, in Northcott, M., (ed.), 1998, Urban Theology, a reader. London: Cassell, $121-126$.

Smith, A., 1863, An inquiry into the nature and the causes of wealth of nations. www2.hn.psu.edu/faculty/jmanis/adam-smith/WealthNations.pdf, accessed 2 November 2014.

Steward, J. 1994. Biblical Holism: Where God, People and Deeds Connect. An interactive Workshop. Melbourne: World Vision Australia. 
Tshwane Leadership Foundation, Inkululeko Community Centre, http://www.tlf.org.za/inkululeko-community-centre/

United Nations Development Programme, 1990, Human development report 1990: Concept and Measurement of human development. New York: Oxford University Press.

Silber, J., \& Yalonetzky, G., 2014, Measuring multidimensional deprivation with dichotomised and ordinal variables, In Betti, G. and Lemmi, A. (eds), Poverty and Social Exclusion: New methods of analysis. London / New York: Routledge.

The Fourfold Gospel, 2008, Commentary on Luke, in Phil Lindner, Power BibleCD. Chicago: Online Publishing Inc.

West, G and the Ujamaa Centre staff. 2011. Doing Contextual Bible Study: $A$ resource manual. Pietermaritzburg: The Ujamaa Centre for Biblical and Theological Community Development and Research. 